\title{
Effects of Team Structure on Innovation Performance: An Empirical Study
}

\author{
Miha Prebil \\ The Centre of Excellence for Biosensors, Instrumentation and Process Control, Solkan, Slovenia \\ Mateja Drnovšek \\ University of Ljubljana, Ljubljana, Slovenia
}

\begin{abstract}
Teamwork is gaining increasing attention in a broader management research. In addition to previous research on the relationship between team structure and innovation performance, this study draws from an interesting experience-based theory advanced by Kelley and Littman (2005), which examines teams from design thinking perspective, and tests its contributions and effects on team's innovation performance. According to Kelley and Littman any team should include the following team roles: The anthropologist, the experimenter, the cross-pollinator, the hurdler, the collaborator, the director, the experience architect, the set designer, the storyteller, and the caregiver. We develop theoretical logics to explain how team structure that includes these key team roles and competences lead to a better innovation performance, and propose pertinent hypotheses. Experimental-empirical research and quantitative analysis were used in the study. The study conducted multiple experiments on three samples: a group of foreign entrepreneurship students, a group of technical students, and an additional group of randomly selected individuals, aged between 20 and 58, with diverse backgrounds. A special approach was implemented and a new instrument was developed to evaluate individuals in teams. While the results show that team that possess the major competences proposed by Kelley and Littman are more innovative, preliminary results also show that not all team roles are equally important. Moreover, team roles should be allocated equally among members for better collaboration, member satisfaction, and quick response, and within one team, one prevailing personality is optimal in terms of innovativeness. We discuss the implications of our findings for future research and managerial practice.
\end{abstract}

Keywords: innovative team structure, team roles, team formation strategy, design thinking, Kelley’s index, ten faces of innovation, team innovation performance

\section{Introduction}

Increasing global competition, ever increasing requirements for flexibility and adaptability to the unexpected conditions and changes has advanced the salience of how teams are structured in the effective production of innovative goods and services (Guzzo \& Dickson, 1996; Kozlowski \& Ilgen, 2006).

\footnotetext{
* Acknowledgments: The Centre of Excellence for Biosensors, Instrumentation and Process Control are an operation financed by the European Union, European Regional Development Fund and Republic of Slovenia, Ministry of Education, Science and Sport.

Miha Prebil, MSc, The Centre of Excellence for Biosensors, Instrumentation and Process Control.

Mateja Drnovšek, Ph.D., Associate Professor, Faculty of Economics, University of Ljubljana.

Correspondence concerning this article should be addressed to Miha Prebil, The Centre of Excellence for Biosensors, Instrumentation and Process Control_COBIK, Velika pot 22, SI-5250 Solkan, Slovenia. E-mail: miha.prebil@cobik.si.
} 
Consequently, significant attention has been paid to a better understanding of what determinants make teams work effectively. In several studies in the field of business, management and psychology scholars have tried to unveil the factors that affect team performance (Kozlowski \& Bell, 2003). For instance, group cohesion (Mullen \& Copper, 1994), emotional displays (Van Kleef et al., 2009), collective goals (O’Leary-Kelly, Martocchio, \& Frink, 1994), member satisfaction (Feng, Yongjuan, \& Erping, 2009), etc., were all shown as significant predictors of team performance and innovation.

Similarly, more and more ventures are successfully founded by teams (Feeser \& Willard, 1990). An increasing number of success stories from the "start-up" world have emphasized the importance of teamwork in the field of entrepreneurship (Chan, 2009) and broader management research (Guzzo \& Dickson, 1996). Although existing literature has largely contributed to our knowledge about determinants of team performance (Banker, Field, Schroeder, \& Sinha, 1996; Stewart \& Barrick, 2000), there are several remaining unanswered questions. For instance, while existing studies highlight many differences across teams' innovative performance, and underscore the importance of considering composition of team roles in the study, there is less attention paid towards understanding how the composition of team roles impacts innovative performance. In particular, factors affecting teams' performance, creative excellence and innovativeness are still poorly examined (Bygrave \& Timmons, 1992; Henneke \& Luthje, 2007).

Further, evidence shows that team heterogeneity is crucial for product innovativeness (Henneke \& Luthje, 2007), team learning (Clarysse \& Moray, 2004), and firm performance (West, 2007), but little is known so far about processes that lead to successful team formation (Chandler \& Lyon, 2011; Forbes, Borchert, Zellmer-Bruhn, \& Sapienza, 2006). Taken altogether, research in determinants of team innovation performance has been growing over the past few years, with team structure being emphasized as one of the main reasons for variability in innovation performance of teams (Cohen \& Bailey, 1997; DeCusatis, 2008). In particular, individual characteristics and attributes of team members influencing allocation of tasks and authority have been attributed a crucial role in team performance (O’Neill \& Allen, 2011; Peeters, Van Tuijl, Rutte, \& Reymen, 2006), and team innovation (Bell, 2007).

In examining the impact of team roles structure, Belbin's model of team roles has so far gained a lot of research attention. According to Belbin, team roles are defined as a pattern of six factors: personality, mental ability, current values and motivation, field constraints, experience, and role learning. Although Belbin (2010) did not show how much of the variance of a specific role is explained by individual factors, he argued that all roles should acquire a balanced representation in a team (Aritzeta, Swailes, \& Senior, 2007). However, not all studies could verify the Belbin roles' contribution to innovation and performance (Anderson \& Spleap, 2004; Rushmer, 1996). Meanwhile, other role theories and guidelines, such as by Benne and Sheats (1948), Katz and Kahn (1978), Graen and Scandura (1987), Parker (1990), Davis, Millburn, Murphy, and Woodhouse (1992), Spencer and Pruss (1992), and Holland (1997) had gained only limited attention in practice. What makes those findings particularly interesting is, that some of the mentioned models have overlapping roles, whereas some of them are unique to a particular researcher (Senior, 1997).

Many have tried to come up with a perfect formula that would allow forming most innovative teams (Belbin, 1981, 2010; Parker, 1990), but none of the guidelines can be generalized across variety of circumstances. The lack of solid theoretical foundations for studying the impact of team roles composition on innovation performance represents a significant gap in literature and demands attention in order to enable more systematic future research. Despite certain theories have already been validated and well noted, in this research 
we study team roles from a different angle. Our research is grounded in design thinking theory, which has become increasingly popular in innovation activities in firms, with a specific goal to test such team structure that allows a better implementation of design thinking in firms. The basic mechanism of the design thinking is to use the designer's sensibility and methods to match people's needs with what is technologically feasible and what a viable business strategy can convert into customer value and market opportunity” (Brown, 2008). In addition, drawing from design thinking logics, Kelley and Littman (2005) argued that team members' diversity, skills, abilities, responsibilities, and personalities affect team innovation performance. Their findings are upon authors' own fieldwork experiences in working with different teams in very different contexts. Although the ideas that Kelley and Littman are advancing in their theorizing are very appealing, they have yet not been validated in a structured manner. Therefore, the main purpose of the study is to test and verify their empirical theory on 10 innovative roles and its connection to innovation performance in a team on a large sample. In order to do so we use a combination of experimental and quantitative research methods in the contexts of different teams.

Our specific contribution is conceptual and empirical. First, we develop theoretical logics and proposition explaining why team structure that includes key team roles leads to a better innovative performance of teams. Second, we test our proposition using experimental techniques. Third, while most of the existing research on teams was focused either on the micro-level to explore individual member contribution to innovation performance, the leadership style of teams (Oldham \& Cummings, 1996) or the macro-level to explore effects of organizational design, industry specific attributes, prior ties, and demographic homogeneity on teams' performance (Eisenhardt \& Tabrizi, 1995), to our best knowledge not many studies focused studying effects on the team level of research. According to Klein and Kozlowski (2000), examining determinants of organizational effectiveness from the team level of research allows better understanding of intra-team interactions and behaviour as well as its external influences (Glynn, Kazanjian, \& Drazin, 2010). This study therefore investigates the innovation performance of teams depending on members' interactions and personalities. By identifying and validating characteristics of innovative team structure that entrepreneurs should pay specific attention to, we provide practical implications that can help firms enhance their competitiveness.

\section{Literature Review and Hypothesis}

Teamwork facilitates firm innovation because diversity, skills, and knowledge breadth of team members' contributions are more than a simple sum of individuals' contributions (Burpitt \& Bigoness, 1997; Jehn, Northcraft, \& Neale, 1999). Innovation often has seeds in the mind of a creative individual, but requires the whole team to analyze and develop (Tang, 1998). The experience-based theory of team structure effectiveness developed by Kelley and Littman (2005) argued that any team should include 10 different team roles from three major domains: (1) learning (the anthropologist, the experimenter, and the cross-pollinator); (2) organizing (the hurdler, the collaborator, and the director); and (3) building (the experience architect, the set designer, the storyteller, and the caregiver). Kelley and Littman's proposition does not necessarily denote 10 different persons denominated with a single role: The role should be understood as 10 attributes, which can be distributed among any number of team members - one member may possess more than just one role. For each of the roles, its characteristics and task responsibilities are linked to the positive effect they hold on innovation and performance that lead to a higher innovation performance. Drawing from the fact that teamwork depends 
upon individual contributions, and that each of the characteristics and responsibilities has an individual influence on innovation, we expect that a team will be more innovative and effective with members covering each of the roles explained hereinafter (Barrick, Stewart, Neubert, \& Mount, 1998; Stewart \& Barrick, 2000; Tjosvold, Yu, \& Wu, 2009). Below we summarize key roles identified in the Kelley and Littman's (2005) framework and integrate them in the innovation performance literature. In specifics, we emphasize key characteristics of each role and link it to the existing studies that related a specific characteristic with innovation performance.

The learning roles are crucial for the firm's performance, as knowledge provides a basis for a competitive edge and fosters innovation (Cohen \& Levinthal, 1990; Grant, 1996). Learning roles, which include the anthropologist, the experimenter, and the cross-pollinator, are in charge of expanding knowledge by constantly gathering new information.

\section{The Anthropologist}

The anthropologist's task is to observe the market and develop a deep understanding of the latent needs of society and the way people interact with products. He/she tries to see all the important details, particularly of the problem-solving action. The most prominent characteristics of this role are open-mindedness, intuition, and possession of empathy (Kelley \& Littman, 2005, pp. 15-40). In prior research, these three characteristics have been significantly related to innovation performance. First, open-mindedness indicates the degree to which people are open-minded, and like novelty (McCrae \& Costa, 1987). Moreover, it refers to the willingness to tolerate different opinions and consider new unfamiliar ideas (Flynn, 2005; LePine, 2003), which are argued to facilitate good understanding of members and lead to a better team innovation performance (Homan et al., 2008). Furthermore, open-mindedness was shown to positively impact individual's creativity, imagination, and innovativeness (Baer \& Oldham, 2006; Jacoby, 1967). Second, intuition, evolves from experiences and accumulated knowledge, and is most often used in an environment that lacks information (Harper, 1988; Kardes, 2006). Furthermore, intuition proves useful in strategic decisions (Khatri \& Ng, 2000) and can foster creativity and individual innovation performance (Sadler-Smith \& Shefy, 2004; Tesolin, 2007). Third, empathy helps branch out into other skills and integrate them with their deep knowledge, as long as they experience the problem from multiple perspectives to fully understand the latent needs. By combining different insights it allows for creativity and higher innovation performance (Martin, 2009; McDonagh \& Thomas, 2010).

\section{The Experimenter}

His/her task is to make ideas tangible to give a shape to a new concept. He/she embraces failures at early stages to avoid big mistakes later in the process and thus saves money and makes the thinking process more fun, therefore more pleasant to work. The most prominent characteristics of this role are able to experiment, risk-taking, and learning from failures. A person's ability to experiment is crucial for team's performance and new product development, as prototypes (from experimentation) enable more powerful explanation via solution visualization and successful idea evolving (West \& Iansiti, 2003; Wouters \& Roijmans, 2010). Second, risk-taking involves taking bold actions, and is also an important factor that positively affects creativity in terms of idea boldness ( Baucus, Norton, Baucus, \& Human, 2008), firm performance (Antoncic, 2003), and team innovation performance (particularly radical innovation due to higher level of complexity and uncertainty) (Cabrales, Medina, Lavado, \& Cabrera, 2008; Rhee, Park, \& Lee, 2010). Moreover, experimentation and trial and error learning improve the development process and foster creativity and organizational innovation 
performance (Cannon \& Edmondson, 2005; Thomke, 2003).

\section{The Cross-Pollinator}

His/her role is to provide knowledge breadth to the team. This team role facilitates combining knowledge, i.e., to connect general knowledge, experiences, skills, hobbies to the problem in the area of expertise. It enables brining new perspectives on how to utilize the expertise knowledge in many different aspects of life to the team (Brown \& Katz, 2009; Kelley \& Littman, 2005, pp. 67-90). The variety of knowledge and skills of this role enhances opportunity recognition (Kogut \& Zander, 1992), new product development (Leonard-Barton, 1995), creativity and firm's innovation (Sakkab, 2007). Finally, it was demonstrated that curiosity has a positive effect on creativity and innovation performance (Fleming, 2004; Sakkab, 2007).

The set of roles that concentrate on organizing are salient for moving ideas forward in organizations. Organizing is essential to teams as it provides a path to follow, to connect, and to integrate all the members into a team by setting goals and motivating other team members. These roles also manage team resources such as time, effort, and financial resources (Kelley \& Littman, 2005).

\section{The Hurdler}

$\mathrm{He} / \mathrm{she}$ is the entrepreneur of the team, persistent, optimistic and determined, with great problem-solving skills. He/she follows the path to the goal he/she believes in and successfully overcomes obstacles that emerge in the way. In the past, persistence has been positively related to innovation activity, as it helps to complete a variety of tasks over time no matter what (Wong, Tjosvold, \& Liu, 2009). Optimistic individuals are also more effective problem-solvers (Peterson, Owens, Tetlock, Fan, \& Martorana, 1998), as they are more open to new knowledge and experimentation (Levinthal \& March, 1993), more open to new challenges (Seligman \& Nathan, 1998), pay more attention to information (Aspinwall, Richter, \& Hoffman Iii, 2001), and more likely react to problems (Geers, Handley, \& McLarney, 2003), which result in a higher problem recognition (Papenhausen, 2004) and individual innovation performance (Gary, 2003).

\section{The Collaborator}

The role of collaborator is to take care of the team, to assign roles to team members, depending on the problem set and the skills needed, and to inspire teams with confidence (Kelley \& Littman, 2005, pp. 113-140). $\mathrm{He} / \mathrm{she}$ brings people together to get things done and ties the group together in challenging times. In the literature, collaboration has been recognized as an essential part in fostering innovation activity through idea generation (Barczak, Lassk, \& Mulki, 2010; Brown \& Katz, 2009), creativity (Alves, Marques, Saur, \& Marques, 2007), speeding up the product development process (Brown \& Eisenhardt, 1995; Schippers, West, \& Dawson, 2010), and better predictions of environmental changes (Ambrose \& Harris, 2009; Hansen \& Oetinger, 2001). The collaborator's main goal is to ensure that the team is used to its full potential in attaining innovation performance.

\section{The Director}

Among the organizing roles, the director is the operative manager of the team. He/she needs to find talented individuals, compose a team, and direct the team towards a goal. The director helps to spark creativity and instils the team with inspiration, motivation, and empowerment (Kelley \& Littman, 2005, pp. 141-164). Similarly, empowerment is important for the creation of trust (Brunetto \& Farr Wharton, 2007), autonomy and power in decision-making (Spreitzer, Kizilos, \& Nason, 1997), proactiveness, open communication, and shared vision and common goal (Ahmed, 1998), which have all been shown to lead to enhanced performance and 
organizational innovation performance (Jung, Chow, \& Wu, 2003).

The building roles integrate information gathered by the learning roles with the empowerment of the organizing personas into a combination that allows and fosters innovation.

\section{The Experience Architect}

$\mathrm{He} / \mathrm{she}$ creates unique consumer experiences to connect at a deeper level with the consumer's latent needs and satisfy market needs. By having the capability of transforming a product or service into an extraordinary experience (Kelley \& Littman, 2005, pp. 165-192), the role fosters innovation performance. Indeed, design literature suggests that focusing on the functional performance of products is not sufficient; innovating firms need to consider a product's emotional satisfaction and market latent needs as well (Leavy, 2010; Y. Li, Wang, X. Li, \& Zhao, 2007). Many contemporary business success stories relate to new experiences (Martin, 2007, 2009); companies such as Apple, P\&G, Four Seasons, Red Hat, Cirque de Soleil brought to the market what people had not even known they need or want.

\section{The Set Designer}

$\mathrm{He} /$ she has the capability of transforming ordinary work environments into a powerful tool that stimulates creativity and fosters innovation by affecting participants' behaviour. The work environment was determined as an important factor in stimulating an individual's creativity, affecting creative performance and innovation as a result (Oldham \& Cummings, 1996). The work environment is salient to individuals' creativity and innovation performance (Amabile, Conti, Coon, Lazenby, \& Herron, 1996).

\section{The Storyteller}

The storyteller builds morale and environmental awareness by fostering the transmission of values, emotions, and objectives through fascinating stories. Stories have a greater power of persuasion than any other facts or reports and are also the channel through which knowledge, norms, and values are exchanged and shared in the pursuit of emotional connection (Boyce, 1996). They enhance trust and commitment through greater understanding, provide new perspectives on the problem, and are a source of inspiration and simulation. The storyteller enforces new ways of considering market needs, which normally results in an improved product, consumer experience, and innovation performance (Beckman \& Barry, 2009; C. Heath \& D. Heath, 2007; Sole \& Wilson, 1999). He/she also has a specifically instrumental role when the team pursues radical innovation (Beckman \& Barry, 2009; Sole \& Wilson, 1999).

\section{The Caregiver}

$\mathrm{He} / \mathrm{she}$ is a customer-focused role with strong empathy to promote and further enhance the consumer experience. His/her customer-focus and empathy enable him/her to promote and further enhance the consumer experience, by making people feel like they are the only customers in the world and that a certain product or a service is specially designed for them (Kelley \& Littman, 2005, pp. 215-240). The caregiver is able to step into the customer's shoes (Ambrose \& Harris, 2009), which results in much greater innovation performance, as many new ideas are exposed (Li et al., 2007; Wylant, 2008).

Above we showed how each of the roles advanced by Kelley and Littman (2005) is related to innovation performance by itself. Given that, we argue that teams that include all of the roles discussed above should also be significantly related to innovation performance (Barrick et al., 1998; Stewart \& Barrick, 2000; Tjosvold et al., 2009). This leads us to propose:

Hypothesis: Team structure that includes the roles proposed by Kelley and Littman (2005) will lead to 
better innovation performance than team structure that includes a random combination of individuals.

In this case, "a role" is considered as an attribute of a team structure and is not necessarily linked to one team member only. Moreover, each member of a team can possess more than just one role.

\section{Research Design}

\section{Research Strategy, Measures, and Data Analysis}

In order to test our hypothesis a combination of qualitative and quantitative research methods was used (Bryman, 2006; Tashakkori, 2006). Given the nascency of this research field the qualitative methodological approach was found appropriate to explore the motives, feelings, values, attitudes, and perceptions that underlie and influence the behaviour of individuals in a team (Merriam, 1998; Patton, 2002). Based on qualitative theory, experiments were used to get better insight into the phenomenon within its real-life context (Denzin \& Lincoln, 1994; Patton, 2002; Yin, 2009) and to understand underlying emotions and cognitions within a team (Sørensen, Mattsson, \& Sundbo, 2010). Quantitative research (linear regression) was used to provide additional support to the relationship between the presence of team roles and organizational innovation.

Given the longitudinal nature of this research multiple experiments were used as a qualitative research tool to consider different cases for replication. Indicative guidelines by Yin (2009) and Patton (2002) were followed on how to perform experiment to have a control over actual behavioural events and simultaneously focus on contemporary events (Denzin \& Lincoln, 1994). However, recommendations regarding qualitative research design are somewhat loose, which leaves a lot of room for a subjective interpretation of the researcher. In what follows, the research design that was used for the purposes of this research is explained.

As Kelley and Littman's theory comes from the authors' long-term observations of how teams function, an experiment was designed in similar settings within which the original findings emerged. In such setting team members work together for a longer period of time and therefore know each-other's advantages, weaknesses, and interactions better. The experimental phase started with an observation of teams of international students and teams of technical student. Additionally, a deeper understanding of the same phenomenon in the short run was desired. Therefore a one-day experiment was conducted.

Three different samples were involved in the experiment. They were selected in a way that allowed us long- and short-term observation as well as international participation. The duration of observed sample and each experiment varied, as the intention was to get a deeper understanding of effect of different team structures (different roles) and intra-team interactions on innovation in different time frames, which were distinctive of individual tasks. All participants performed in teams and were given a problem set to solve. During the task their roles were assessed and compared to Kelley and Littman's, and their solution was reviewed by a group of independent experts.

The first sample was composed of 13 teams of international students enrolled in the entrepreneurship course at the local university. They were observed working on two different projects during a six month time frame to find out, how team roles interact on a long term and how individuals coming from different cultures and countries operate. Teams were observed once a week during workshops to allocate different roles that appeared during the process and their variable interactions. The second sample included 11 teams of engineering major students enrolled at the local university. They were observed working on a single project during a four month time frame also once a week on their workshops. The third sample consisted of 10 teams of randomly selected individuals, aged between 20 and 58, with diverse backgrounds. They were observed 
during a one-day experimental study to get an insight of roles' interactions when performing quick tasks.

During the process, team interactions were carefully monitored and recorded to get an in-depth insight of team dynamics and to identify member team roles. To obtain more detailed information and to simplify research process, a structured questionnaire was developed on the basis of our observation. Our survey instrument included questions about team members and was tested on a group of post-graduate students at the local university prior to being used in the experiment. The questionnaire proved to be an adequate substitute for observation, as the answers of the existing roles were similar to what we observed and was then used to calculate the independent variable - team role score. For the purposes of this research the name Kelley's index was suggested to designate team role score.

After a task completion, each team member was asked to evaluate his/her team members. In terms of structure and organization, the left side of the questionnaire held descriptions of each of the 10 roles, whereas the right side contained a table to fill out. Each member of the team had one minute to read the characteristics of a certain role (the anthropologist). After, more information on a specific role was provided by interrogator in order to prevent misunderstanding. Next, the team members had one minute to evaluate the mentioned role on the sample of their members, including themselves and attribute it to any individual. They repeated the process outlined above for each of the 10 roles. Each member of the team was able to select a maximum of two people who in his/her opinion possessed the mentioned characteristics, and rated them on a scale from 1 (the characteristics are poorly expressed) to 5 (the mentioned characteristics can be completely related to the person). If no such characteristics existed in the team, the person was requested to leave it blank. The independent variable, which delineated Kelley's index, was measured through questions. Individual scores were then used to calculate team role score with only the role scores of members receiving at least $50 \%$ of the voted size being considered. The index was calculated as the sum of individual shares (the amount of rates compared to the maximum amount of rates a person can get) and measured the number of expressed roles in a team (out of 10).

The dependent variable (team's innovation performance) was assessed by independent experts' opinion. Three experts individually evaluated teams' projects in terms of innovation performance on a scale $0-100 \%$. For the purposes of the study the average rate of innovation performance for each team was calculated. It is again important to emphasize that not all roles existed in each team and that team members can associate with multiple roles.

\section{Sampling}

Sample 1 was composed of international students of Entrepreneurship, aged between 19 and 24. They were requested to finish two projects (Cases 1 and 2), each during a five week time frame. Case 1: The problem involved designing a new cafeteria on the school's patio. They were assigned to six different teams, consisting of five to six members each, and were given five weeks to finish the project. Throughout the execution of the project, the teams were regularly monitored and each member needed to fill out the questionnaire on teamwork. Team innovation performance was also assessed at that point by three experts. Case 2: The second case was conducted on the same group of students, but with different team composition. Students were requested to form teams volitionally. There were seven teams in this case, each consisting of four to five members. They were given three similar problem sets to choose from and were allowed six weeks to finish their projects. Throughout the execution of the project the teams were regularly monitored and each member needed to fill out the 
questionnaire on teamwork. Team innovation performance was also assessed at that point by three experts.

Sample 2 included two groups of students (Cases 3 and 4) majoring in engineering, aged between 18 and 25 years, who were requested to finish two projects within a time frame of three months. Cases 3 and 4: Students were given three months to finish a business project of their own. Based on design thinking principles they had to develop their own idea and then present it in a business plan format. Throughout the execution of the project, the teams were regularly monitored and each member needed to fill out the questionnaire on teamwork. Their presentation, along with the business plan, was rated by independent experts who also evaluated each team's project innovation performance.

Sample 3 included 25 randomly selected individuals, aged 20 to 58, who formed five teams for the first two creative problem sets, and were later on assigned different teams for the next two problem sets. The duration of the tasks was between 8 and 45 minutes. Case 5: Five teams were formed volitionally and were given a "warm-up" task of constructing an instrument for eating any kind of food when on a hike or in the mountains. They had 45 minutes to finish their task. Afterwards they were requested to evaluate each other by filling out the questionnaire. Three experts assessed team innovation performance. Case 6: Teams were formed based on the results from the questionnaire in Case 5. Individual scores of the roles they possessed enabled the formation of the following five teams: (1) Team 1 included participants who had developed several strong personal team roles in the first problem set; (2) Teams 2 and 3 consisted of individuals who had not significantly expressed any of the roles in a team; (3) Teams 4 and 5 were composed of individuals who had expressed a maximum of two roles, and, as a combination of members, covered all 10 necessary roles. These teams were given two problem sets. The first was a short, impulsive one, whereas the second was similar to the previous experiment. Two different tasks that required different completion times were selected to gain insight into the effect of stress and restraints. As the teams remained the same during both tasks, the role score index was evaluated with one questionnaire for both tasks after the second task was finished. Furthermore, innovation performance was calculated as an average of both problem set scores. In the first problem, teams were given a short team building exercise. The first task included construction of a floating boat within eight minutes. If the team completed the task, it was given the opportunity to race with its boat by blowing into it in a small pool. The teams' innovation performance was rated accordingly to exercise rules. The second problem required designing an innovative solution to existing camera bags (with specimen). At the end of 45 minutes, team members evaluated their partners with a questionnaire. The team role score was then calculated as the sum of both individual scores, and experts' rated innovation performance of the solution.

\section{Data Analysis and Results}

The qualitative research results (observation, interviews) provided evidence to support our hypothesis that the number of roles influences a team's innovation performance. Teams that had more roles demonstrated higher innovation performance in their solutions. In addition, as the sample was of sufficient size, a linear regression analysis was used to assess the effect of the roles on innovation performance. The hypothesis was tested using a linear regression model of standardized coefficients. The following regression coefficient was obtained:

$$
\text { Innovation performance }=0.68 \times \text { Kelley's index }
$$

which denotes that innovation performance is predicted to increase by 0.68 when Kelley's index goes up by one. "Kelley's index" in the regression model marks the overall team role score (the number of the roles that were 
formed in a team) that was calculated from questionnaire data. The significance level of the coefficient was $0.000(t=5.518)$. The coefficient of determination $\left(R^{2}\right)$ was 0.46 , indicating that $46 \%$ of the total variance in innovation performance was explained by this linear regression model, which left the rest of the variance (54\%) as variability of the data from the model. Unquestionably, the argumentation above provides sufficient reasoning to confirm our hypothesis, as Kelley's index measured the number of expressed roles in a team. Accordingly, teams of members covering a larger portion of the roles proposed by Kelley and Littman are more innovative than teams that encompass a random combination of members.

The results are presented in Table 1. In what follows, the results of the executed experiments are discussed in detail, based on our monitoring of the teams. Case 1 supported the idea that teams that achieve a better Kelley's index are more innovative. The upper three teams according to innovation performance rank were also the upper three teams based on Kelley's index rank. The team that achieved the highest Kelley's index got the second best result in innovation performance, whereas the team that placed first on the innovation performance scale reached the second highest Kelley's index. Teams 6 and 2 attained 3rd and 4th place according to their Kelley's index and the same places in innovation performance. In addition, teams 3 and 5, whose solutions to the problems were the least innovative, scored the lowest Kelley's index. Case 2 included seven teams. The results of this experiment further support the hypothesis. Teams that ranked in the upper half of Kelley's index results achieved better cumulative innovation performance rank as opposed to the lower half of ranked teams.

Table 1

Standardized Values Ranks

\begin{tabular}{|c|c|c|c|c|c|c|c|}
\hline Case & Team & $\begin{array}{l}\text { Kelley's } \\
\text { index }\end{array}$ & $\begin{array}{l}\text { Innovation } \\
\text { performance }\end{array}$ & $\begin{array}{l}\text { Kelley's index } \\
\text { rank }\end{array}$ & $\begin{array}{l}\text { Innovation } \\
\text { performance rank }\end{array}$ & $\begin{array}{l}\text { Standardized } \\
\text { Kelley’s index rank }\end{array}$ & $\begin{array}{l}\text { Standardized innovation } \\
\text { performance rank }\end{array}$ \\
\hline \multirow[t]{6}{*}{ Case 1} & Team 1 & 5.10 & 91 & 2 & 1 & -0.80178 & -1.33631 \\
\hline & Team 4 & 6.45 & 89.3 & 1 & 2 & -1.33631 & -0.80178 \\
\hline & Team 6 & 4.35 & 83.3 & 3 & 3 & -0.26726 & -0.26726 \\
\hline & Team 2 & 3.96 & 82.3 & 4 & 4 & 0.26726 & 0.26726 \\
\hline & Team 3 & 1.32 & 70 & 6 & 5 & 1.33631 & 0.80178 \\
\hline & Team 5 & 3.20 & 64.3 & 5 & 6 & 0.80178 & 1.33631 \\
\hline \multirow[t]{7}{*}{ Case 2} & Team 4 & 5.16 & 95.0 & 4 & 1 & 0 & -1.22559 \\
\hline & Team 3 & 8.55 & 94.2 & 1 & 2 & -1.38873 & -0.77406 \\
\hline & Team 7 & 3.96 & 89.2 & 5 & 2 & 0.46291 & -0.77406 \\
\hline & Team 8 & 6.72 & 85.0 & 2 & 4 & -0.92582 & 0.12901 \\
\hline & Team 9 & 3.75 & 75.0 & 6 & 4 & 0.92582 & 0.12901 \\
\hline & Team 6 & 2.85 & 69.2 & 7 & 6 & 1.38873 & 1.03208 \\
\hline & Team 2 & 5.50 & 63.3 & 3 & 7 & -0.46291 & 1.48361 \\
\hline \multirow[t]{5}{*}{ Case 3} & Team 2 & 4.48 & 96.3 & 1 & 1 & -1.26491 & -1.26491 \\
\hline & Team 1 & 4.04 & 88.8 & 2 & 2 & -0.63246 & -0.63246 \\
\hline & Team 3 & 3.68 & 86.3 & 3 & 3 & 0 & 0 \\
\hline & Team 5 & 3.64 & 85.0 & 4 & 4 & 0.63246 & 0.63246 \\
\hline & Team 4 & 1.52 & 67.5 & 5 & 5 & 1.26491 & 1.26491 \\
\hline \multirow[t]{6}{*}{ Case 4} & Team 1 & 7.10 & 95 & 1 & 1 & -1.33631 & -1.33631 \\
\hline & Team 3 & 5.76 & 85 & 2 & 2 & -0.80178 & -0.80178 \\
\hline & Team 2 & 4.88 & 84 & 3 & 3 & -0.26726 & -0.26726 \\
\hline & Team 5 & 4.65 & 83 & 4 & 4 & 0.26726 & 0.26726 \\
\hline & Team 6 & 2.80 & 76 & 6 & 5 & 1.33631 & 0.80178 \\
\hline & Team 4 & 2.96 & 73 & 5 & 6 & 0.80178 & 1.33631 \\
\hline
\end{tabular}


(Table 1 continued)

\begin{tabular}{llllllll}
\hline Case & Team & $\begin{array}{l}\text { Kelley’s } \\
\text { index }\end{array}$ & $\begin{array}{l}\text { Innovation } \\
\text { performance }\end{array}$ & $\begin{array}{l}\text { Kelley’s index } \\
\text { rank }\end{array}$ & $\begin{array}{l}\text { Innovation } \\
\text { performance rank }\end{array}$ & $\begin{array}{l}\text { Standardized } \\
\text { Kelley’s index rank }\end{array}$ & $\begin{array}{l}\text { Standardized innovation } \\
\text { performance rank }^{*}\end{array}$ \\
\hline Case 5 & Team 1 & 5.32 & 87.5 & 2 & 1 & -0.63246 & -1.26491 \\
& Team 2 & 4.52 & 85.0 & 3 & 2 & 0 & -0.63246 \\
& Team 3 & 6.12 & 85.0 & 1 & 3 & -1.26491 & 0 \\
& Team 4 & 3.52 & 74.0 & 4 & 4 & 0.63246 & 0.63246 \\
& Team 5 & 2.96 & 62.5 & 5 & 5 & 1.26491 & 1.26491 \\
Case 6 & Team 5 & 3.48 & 85.0 & 3 & 1 & 0 & -1.26491 \\
& Team 4 & 7.68 & 74.2 & 1 & 2 & -1.26491 & -0.63246 \\
& Team 3 & 3.00 & 73.8 & 4 & 3 & 0.63246 & 0 \\
& Team 1 & 1.48 & 65.0 & 5 & 4 & 1.26491 & 0.63246 \\
& Team 2 & 5.56 & 53.3 & 2 & 5 & -0.63246 & 1.26491 \\
\hline
\end{tabular}

Note. ${ }^{*}$ Standardized within a case.

Results of the Case 3, which was composed of technical students, provided supporting evidence for the existence of a relationship between the 10 roles and team innovation performance. Kelley's index rank that each team attained matched entirely with their innovation performance rank. Likewise, the results of the Case 4 proved almost identical, with a minor deviation in the two teams that achieved the lowest Kelley's index rank.

In Case 5, three teams that scored at the top of Kelley's index scale took the top three positions in the innovation performance scale rank, with a slightly different distribution. Furthermore, teams 4 and 5, which reached the lowest position with regard to their Kelley's index, also hit the bottom two positions in their innovation performance rank. On the other hand, the results in Case 6 align with the hypothesis, despite the fact that one team (team 2) did not co-operate as expected. According to observation and members' comments, they did not realize the seriousness of the task presented. However, despite noticed deviations within specific experiments and the results differentiating and varying across samples, the overall study shows the significant importance of Kelley's index when predicting team innovation performance.

In the following paragraphs results and activities of each of the teams in the Case 6, which tested how these 10 types of roles work together in real time settings, are discussed. The first team included those individuals that had achieved the highest Kelley's index individually in the Case 5, which in practice meant that they had significantly developed and adopted three or more different roles. The team was unsuccessful in completing the first task, which lasted eight minutes. A clash of roles appeared, team productivity was inhibited by members spending too much time figuring out and determining their roles. Members within a team were not working as a team. Rather, they were acting as a team of non co-operating individuals, each of them trying to find a solution individually. When asked, participants expressed their feelings, noting that the exercise was one of the worst teamwork experiences of their lives. This inability to collaborate also reflected in their Kelley's index. According to normal expectations, a team of individuals with high individual Kelley's index would ultimately lead to a team with a high Kelley's index. On the contrary, their strong personalities suppressed their team roles and they rated each other poorly in the questionnaire at the end of the project.

However, despite difficulties experienced during the first task, the team achieved much better results in the second task, which was of a longer duration. Albeit only three members in the team actually participated in the problem-solving activity, their collaboration was taxing and full of adaptation. They came up with a solution that brought them the highest innovation performance score (of all cases). Accordingly, we can assume that innovation performance is positively related to the number and strength of roles mostly in the long run and if 
the roles do not overlap. Notwithstanding, their average innovation performance score was, due to the equivalent weight of the both tasks, still low and matched completely with the low Kelley's index they attained.

The second and the third team were organized with participants that had not developed any significant role in their team in the first part of the experiment. According to their internal evaluation and observation, some of these individuals developed significantly more roles than in the first team, therefore the Kelley's index of newly composed teams yielded a higher value. This can be due to the fact that their team roles in Case 5 might not have been expressed and developed to its full potential. However, the same two teams ranked in the bottom part of the innovation performance rank in Case 6, despite one of them achieving a rather good Kelley's index. Observation of the work process offered a good explanation: The members of the team were unwilling to fill in the questionnaires carefully and thoughtfully, as some of the members were in a hurry to leave the experiment for some reason. In addition, the members of the team were not in a mood and did not take the experiment seriously enough (their solution to the problem set was innovative but also unrealistic. Such circumstances possibly led to a bad result in innovation performance and a quite good Kelley's index (they were too generous evaluating each other, because they did not want to offend each other).

The final step included organization of the fourth and the fifth team of participants out of the participants that had expressed a maximum of two roles in the first part and whose roles did not overlap. Teams that would cover as many of the roles as possible were formed. These two teams achieved the highest rank in combined innovation performance from both problem sets. In the first problem set, which required a quick response, both teams acted as a great team and came to brilliant solutions. Simultaneously, their high Kelley's indexes were congruent to their innovation performance rank. Moreover, according to their comments, these two teams really went along well and enjoyed working together. Great work conditions, member satisfaction, roles that did not overlap and yet covered all 10 of the roles, no strong personalities with than one developed role, no one that would put himself/herself forward by any means; all these components seemed to be essential to the teams' success and innovation performance. The experiment settings and findings are presented in Table 2.

Table 2

Experiment Findings

\begin{tabular}{|c|c|c|c|c|c|c|c|}
\hline Sample & \begin{tabular}{|l|} 
Experiment \\
number
\end{tabular} & Team & Duration & Settings & Task & Findings & $\begin{array}{l}\text { General } \\
\text { findings }\end{array}$ \\
\hline \multirow[t]{2}{*}{\begin{tabular}{|l|} 
Sample 1: \\
International \\
students of \\
entrepreneurship
\end{tabular}} & Case 1 & 6 & five weeks & $\begin{array}{l}\text { Individuals } \\
\text { chose their own } \\
\text { teams }\end{array}$ & $\begin{array}{l}\text { Designing a new } \\
\text { cafeteria }\end{array}$ & $\begin{array}{l}\text { Teams that achieved } \\
\text { higher Kelley’s index } \\
\text { ranked higher on } \\
\text { innovation performance } \\
\text { scale. }\end{array}$ & \multirow{4}{*}{$\begin{array}{l}\text { Teams that } \\
\text { encompass } \\
\text { more roles are } \\
\text { more } \\
\text { innovative (no } \\
\text { matter which } \\
\text { roles). }\end{array}$} \\
\hline & Case 2 & 7 & five weeks & $\begin{array}{lr}\text { Teams } & \text { were } \\
\text { formed } & \text { by } \\
\text { instructor } & \end{array}$ & $\begin{array}{ll}\text { Designing } & \text { a } \\
\text { marketing } & \text { plan } \\
\text { for } & \text { Slovenian } \\
\text { brand } & \end{array}$ & $\begin{array}{l}\text { Teams ranked in the upper } \\
\text { half of Kelley's index } \\
\text { results achieved better } \\
\text { cumulative innovation } \\
\text { performance rank. }\end{array}$ & \\
\hline \multirow[t]{2}{*}{$\begin{array}{l}\text { Sample 2: } \\
\text { Engineering } \\
\text { major students }\end{array}$} & Case 3 & 5 & 11 weeks & $\begin{array}{l}\text { Individuals } \\
\text { chose their own } \\
\text { teams }\end{array}$ & $\begin{array}{l}\text { Business plan } \\
\text { by their choice }\end{array}$ & $\begin{array}{l}\text { Kelley’s index rank that } \\
\text { each team attained } \\
\text { matched entirely with } \\
\text { their innovation } \\
\text { performance rank. }\end{array}$ & \\
\hline & Case 4 & 6 & 11 weeks & $\begin{array}{l}\text { Individuals } \\
\text { chose their own } \\
\text { teams }\end{array}$ & $\begin{array}{l}\text { Business plan } \\
\text { by their choice }\end{array}$ & $\begin{array}{l}\text { Kelley's index rank that } \\
\text { each team attained matched } \\
\text { with their innovation } \\
\text { performance rank. }\end{array}$ & \\
\hline
\end{tabular}


(Table 2 continued)

\begin{tabular}{|c|c|c|c|c|c|c|c|}
\hline Sample & \begin{tabular}{|l|} 
Experiment \\
number
\end{tabular} & Team & Duration & Settings & Task & Findings & General findings \\
\hline \multirow[t]{2}{*}{\begin{tabular}{|l|} 
Sample 3: 25 \\
random \\
individuals, \\
aged between 20 \\
and 58
\end{tabular}} & Case 5 & 5 & $45 \mathrm{~min}$ & $\begin{array}{l}\text { Individuals } \\
\text { chose their own } \\
\text { teams }\end{array}$ & $\begin{array}{l}\text { Designing an } \\
\text { instrument for } \\
\text { eating out }\end{array}$ & $\begin{array}{l}\text { Teams that scored at the } \\
\text { top three of Kelley's } \\
\text { index scale took the top } \\
\text { three positions in the } \\
\text { innovation performance } \\
\text { scale rank. }\end{array}$ & \\
\hline & Case 6 & 5 & $\begin{array}{l}8 \min +45 \\
\min \end{array}$ & $\begin{array}{l}\text { Teams were } \\
\text { formed based on } \\
\text { questionnaire } \\
\text { results in Case } \\
5^{*}\end{array}$ & $\mid \begin{array}{lr}\text { Construction } \\
\text { of a r boat; } \\
\text { designing r a } \\
\text { camera bag }\end{array}$ & $\begin{array}{l}\text { Teams with higher } \\
\text { Kelley's index ranked } \\
\text { higher on innovation } \\
\text { performance. }\end{array}$ & $\begin{array}{l}\text { (1) Team roles } \\
\text { should r be } \\
\text { allocated equally } \\
\text { among members } \\
\text { (each member } \\
\text { should not adopt } \\
\text { more than three } \\
\text { roles); and (2) } \\
\text { within the team, } \\
\text { one prevailing } \\
\text { personality (a } \\
\text { person that } \\
\text { adopts the most } \\
\text { roles) is optimal } \\
\text { in terms of } \\
\text { innovation } \\
\text { performance. }\end{array}$ \\
\hline
\end{tabular}

Note. " Individual scores of the roles they possessed enabled the formation of the following five teams: (1) Team 1 included participants who had developed several strong personal team roles in the first problem set; (2) Teams 2 and 3 consisted of individuals who had not significantly expressed any of the roles in a team; and (3) Teams 4 and 5 were composed of individuals who had expressed a maximum of two roles, and, as a combination of members, covered all 10 necessary roles.

\section{Discussion}

This research was drawn from an interesting, experience based proposal how team composition may affect its innovation performance (Kelley \& Littman, 2005). The aim was to bring together disparate research on the effects of team role composition on innovative performance in teams by testing Kelley and Littman's theory on team structure and how it has an effect on innovation. In specifics, the study proposes that the team structure that will include all roles as proposed by Kelley and Littman (2005) will attain better innovation-related results than a randomly assigned team. The study can be seen as a starting point of empirical research on the role of team composition in innovation performance.

A multiple-experiment research was conducted to test Kelley and Littman's theory that varied team roles are needed for a better team level innovation performance. This hypothesis was supported with data from three different samples and several cases within each sample. Obviously, the initial motivation for this study was to provide advice for entrepreneurs and managers on how to structure teams with the goal of attaining the best possible team innovation performance. To examine Kelley and Littman's proposed roles the work of 34 teams was followed and recorded within a six month time frame. The data collected were analysed with qualitative and quantitative research methods. The results provided support for the core proposition of the theory by Kelley and Littman's theory that a balanced team structure leads to better innovation results. Furthermore, the empirical examination additionally complements Kelley and Littman's guidelines with unique insights: It provides recommendations on how to optimally allocate roles among members in a team and suggests a hands-on approach to measuring team innovation performance and composing a team. 
The study shows that innovation performance is positively impacted by Kelley's index, which denotes the number of expressed roles in a team. Based on our findings conclusions are drawn as follows:

(1) Teams that encompass more roles proposed by Kelley and Littman are more innovative (no matter which roles).

Moreover, our study finds some specific characteristics related to this theory and makes its own contribution.

(2) Team roles should be allocated equally among members for a better collaboration, member satisfaction, and intra-team interactions.

(3) Each member should not adopt more than three roles.

(4) Within the team one prevailing personality (a person that adopts the most roles) is optimal in terms of innovation performance.

(5) Finally, teams that cover all 10 roles are more innovative.

The study proposes that managers and entrepreneurs should in structuring their team's aim to include all of the 10 suggested team roles. However, it may happen that a specific role is not permanently present in different teams. A person might possess a predisposition for certain roles, but the nature and behaviour of the roles are dynamically dependent on other roles expressed in a team. Similarly, in assessing a team's performance, questionnaires are meant to evaluate members of a certain team and cannot be used to evaluate individuals that are not part of the team. Therefore it is recommended that when a team is organized, individuals should be tested within this specific team. This team should be requested to solve at least one one-hour problem set and should be evaluated at the end of the exercise by questionnaires and observation. If the roles of the members are covered and equally arranged, then such team will work to its full potential. In contrast, if the roles are not expressed, it could mean one of the following: (1) Members of a team do not meet the requirements - they are unexpressed and do not match to problem-solving related assignments; or (2) The team consists of too many dominant and strong members, which ultimately inhibits the development of the roles and overall creativity of the team. The solution could be to form a team with different representation of the members, or try to determine participants that cause such a condition and allocate them responsibilities of the roles that are missing in a team. In essence, the process of finding an optimal team is very much of a trial and error concept and requires persistence in finding a well-working balance. However, it is worth to invest more time to construct team as the innovation activity may escalate profoundly.

\section{Limitations and Future Research}

There are several limitations that should be considered in interpreting findings from this study. The first limitation is related to the boundary condition - the context specificity of team's work. This limitation can best be explained with the following example: Different participants have different styles of engaging in the working process, which can influence team output. There is a question of whether the 10 types could work together in a productive manner in every single circumstance, or whether there would arise a clash of roles that undermines the creativity and performance of the team under certain conditions. Our results indicate that a team works in a productive manner when all 10 roles are adopted and allocated equally among team members. However, future research should focus on additional verification and examination of this particular insight, paying specific attention to interactions among roles and contextual conditions.

The second limitation of the study relates to role allocation among team members and team members' 
possession of multiple roles. The study did not take into consideration the optimal combination and number of roles, an individual member shall master. There is an opportunity for future research to determine the most compatible and complementary role groups that may be possessed by an individual member in order to maximize effectiveness.

Third, this study did not examine the importance of individual roles and how different roles affect innovation activity. There exists a need to assess contribution of individual roles to team's innovation performance and to determine which roles are more crucial to include in a team.

Fourth, the study was conducted in a non-stress environment. Despite the nature of problem sets being realistic, the money component was not present. People tend to accept different, less courageous choices in real life, when their decisions might have severe consequences for them or their firm. There is a need to re-conduct the study in real work settings, in particular with teams that innovate for their living. Finally, the questionnaire used in the study was developed and tested on teams of four to six members. Future work is needed in developing a questionnaire that can fit to any team size.

\section{References}

Ahmed, P. K. (1998). Culture and climate for innovation. European Journal of Innovation Management, 1(1), 30-43.

Alves, J., Marques, M. J., Saur, I., \& Marques, P. (2007). Creativity and innovation through multidisciplinary and multisectoral cooperation. Creativity and Innovation Management, 16(1), 27-34.

Amabile, T. M., Conti, R., Coon, H., Lazenby, J., \& Herron, M. (1996). Assessing the work environment for creativity. Academy of Management Journal, 39(5), 1154-1184.

Ambrose, G., \& Harris, P. (2009). Design thinking. Lausanne: AVA Publishing.

Anderson, N., \& Spleap, S. (2004). An evaluation of gender differences on the Belbin team role self-perception inventory. Journal of Occupational and Organizational Psychology, 77(3), 429-437.

Antoncic, B. (2003). Risk taking in intrapreneurship: Translating the individual level risk aversion into the organizational risk taking. Journal of Enterprising Culture, 11(1), 1-23.

Aritzeta, A., Swailes, S., \& Senior, B. (2007). Belbin’s team role model: Development, validity and applications for team building. Journal of Management Studies, 44(1), 96-118.

Aspinwall, L. G., Richter, L., \& Hoffman Iii, R. R. (2001). Understanding how optimism works: An examination of optimists' adaptive moderation of belief and behavior. In E. C. Chang (Ed.), Optimism and pessimism: Theory, research, and practice (pp. 217-238). Washington, D.C.: American Psychological Association.

Baer, M., \& Oldham, G. R. (2006). The curvilinear relation between experienced creative time pressure and creativity: Moderating effects of openness to experience and support for creativity. Journal of Applied Psychology, 91(4), 963-970.

Banker, R. D., Field, J. M., Schroeder, R. G., \& Sinha, K. K. (1996). Impact of work teams on manufacturing performance: A longitudinal field study. Academy of Management Journal, 39(4), 867-890.

Barczak, G., Lassk, F., \& Mulki, J. (2010). Antecedents of team creativity: An examination of team emotional intelligence, team trust and collaborative culture. Creativity and Innovation Management, 19(4), 332-345.

Barrick, M. R., Stewart, G. L., Neubert, M. J., \& Mount, M. K. (1998). Relating member ability and personality to work-team processes and team effectiveness. Journal of Applied Psychology, 83(3), 377.

Baucus, M., Norton, W., Baucus, D., \& Human, S. (2008). Fostering creativity and innovation without encouraging unethical behavior. Journal of Business Ethics, 81(1), 97-115.

Beckman, S. L., \& Barry, M. (2009). Design and innovation through storytelling. International Journal of Innovation Science, 1(4), 151-160.

Belbin, R. M. (1981). Management teams: Why they succeed or fail. London: Heinemann.

Belbin, R. M. (2010). Team roles at work. Oxford: Butterworth-Heinemann.

Bell, S. T. (2007). Deep-level composition variables as predictors of team performance: A meta-analysis. Journal of Applied Psychology, 92(3), 595-615.

Benne, K. D., \& Sheats, P. (1948). Functional roles of group members. Journal of social issues, 4(2), 41-49. 
Boyce, M. E. (1996). Organizational story and storytelling: A critical review. Journal of Organizational Change Management, 9(5), 5-26.

Brown, S. L., \& Eisenhardt, K. M. (1995). Product development: Past research, present findings, and future directions. Academy of Management Review, 20(2), 343-378.

Brown, T. (2008). Design thinking. Harvard Business Review, 86(6), 84-92.

Brown, T., \& Katz, B. (2009). Change by design: How design thinking transforms organizations and inspires innovation. New York: Harper Business.

Brunetto, Y., \& Farr Wharton, R. (2007). The moderating role of trust in SME owner/managers' decision making about collaboration. Journal of Small Business Management, 45(3), 362-387.

Bryman, A. (2006). Integrating quantitative and qualitative research: How is it done? Qualitative Research, 6(1), 97-113.

Burpitt, W. J., \& Bigoness, W. J. (1997). Leadership and innovation among teams. Small Group Research, 28(3), 414-423.

Bygrave, W. D., \& Timmons, J. A. (1992). Venture capital at the crossroads. Massachusetts: Harvard Business Press.

Cabrales, Á. L., Medina, C. C., Lavado, A. C., \& Cabrera, R. V. (2008). Managing functional diversity, risk taking and incentives for teams to achieve radical innovations. R\&D Management, 38(1), 35-50.

Cannon, M. D., \& Edmondson, A. C. (2005). Failing to learn and learning to fail (intelligently): How great organizations put failure to work to improve and innovate. Long Range Planning, 38(3), 299-319.

Chan, C. S. R. (2009). Teams in the entrepreneurial process: An input-mediator-output-input (IMOI) approach. In G. T. Solomon (Ed.), Academy of management annual meeting proceedings (pp. 1-6). Chicago, IL.

Chandler, G. N., \& Lyon, D. W. (2011). Entrepreneurial teams in new ventures: Composition, turnover and performance. Paper presented at the Academy of Management Proceedings \& Membership Directory.

Clarysse, B., \& Moray, N. (2004). A process study of entrepreneurial team formation: The case of a research-based spin-off. Journal of Business Venturing, 19(1), 55-79.

Cohen, S. G., \& Bailey, D. E. (1997). What makes teams work? Group effectiveness research from the shop floor to the executive suite. Journal of Management, 23(3), 239-290.

Cohen, W. M., \& Levinthal, D. A. (1990). Absorptive capacity: A new perspective on learning and innovation. Administrative Science Quarterly, 35(1), 128-152.

Davis, J., Millburn, P., Murphy, T., \& Woodhouse, M. (1992). Successful team building: How to create teams that really work. London: Kogan Page.

DeCusatis, C. (2008). Creating, growing and sustaining efficient innovation teams. Creativity \& Innovation Management, 17(2), 155-164.

Denzin, N. K., \& Lincoln, Y. S. (1994). Handbook of qualitative research. Thousand Oaks, C.A.: Sage Publications, Inc..

Eisenhardt, K. M., \& Tabrizi, B. N. (1995). Accelerating adaptive processes: Product innovation in the global computer industry. Administrative Science Quarterly, 40(1), 84-110.

Feeser, H. R., \& Willard, G. E. (1990). Founding strategy and performance: A comparison of high and low growth high-tech firms. Strategic Management Journal, 11(2), 87-98.

Feng, L., Yongjuan, L., \& Erping, W. (2009). Task characteristics and team performance: The mediating effect of team member satisfaction. Social Behavior and Personality: An International Journal, 37(10), 1373-1382.

Fleming, L. (2004). Perfecting cross-pollination. Harvard Business Review, 8, 22-24.

Flynn, F. J. (2005). Having an open mind: The impact of openness to experience on interracial attitudes and impression formation. Journal of Personality and Social Psychology, 88(5), 816.

Forbes, D. P., Borchert, P. S., Zellmer-Bruhn, M. E., \& Sapienza, H. J. (2006). Entrepreneurial team formation: An exploration of new member addition. Entrepreneurship: Theory and Practice, 30(2), 225-248.

Gary, L. (2003). Staying positive-Without the illusions. Harvard Management Update, 8(9), 3-5.

Geers, A. L., Handley, I. M., \& McLarney, A. R. (2003). Discerning the role of optimism in persuasion: The valence-enhancement hypothesis. Journal of Personality and Social Psychology, 85(3), 554-565.

Glynn, M. A., Kazanjian, R., \& Drazin, R. (2010). Fostering innovation in complex product development settings: The role of team member identity and interteam interdependence. Journal of Product Innovation Management, 27(7), 1082-1095.

Graen, G. B., \& Scandura, T. A. (1987). Toward a psychology of dyadic organizing. Research in Organizational Behaviour, 9 , 175-208.

Grant, R. M. (1996). Toward a knowledge-based theory of the firm. Strategic Management Journal, 17, 109-122.

Guzzo, R. A., \& Dickson, M. W. (1996). Teams in organizations: Recent research on performance and effectiveness. Annual 
Review of Psychology, 47, 307-338.

Hansen, M. T., \& Oetinger, B. V. (2001). Introducing T-shaped managers: Knowledge management's next generation. Harvard Business Review, 79(3), 107-116.

Harper, S. C. (1988). Intuition: What separates executives from managers. Business Horizons, 31(5), 13-19.

Heath, C., \& Heath, D. (2007). Made to stick: Why some ideas survive and others die. New York: Random House Inc..

Henneke, D., \& Luthje, C. (2007). Interdisciplinary heterogeneity as a catalyst for product innovativeness of entrepreneurial teams. Creativity and Innovation Management, 16(2), 121-132.

Holland, J. L. (1997). Making vocational choices: A theory of vocational personalities and work environments. FL: Psychological Assessment Resources, Inc..

Homan, A. C., Hollenbeck, J. R., Humphrey, S. E., Van Knippenberg, D., Ilgen, D. R., \& Van Kleef, G. A. (2008). Facing differences with an open mind: Openness to experience, salience of intragroup differences, and performance of diverse work groups. The Academy of Management Journal ARCHIVE, 51(6), 1204-1222.

Jacoby, J. (1967). Open-mindedness and creativity. Psychological Reports, 20 (3), 822.

Jehn, K. A., Northcraft, G. B., \& Neale, M. A. (1999). Why differences make a difference: A field study of diversity, conflict, and performance in workgroups. Administrative Science Quarterly, 44(4), 741-763.

Jung, D. I., Chow, C., \& Wu, A. (2003). The role of transformational leadership in enhancing organizational innovation: Hypotheses and some preliminary findings. The Leadership Quarterly, 14(4-5), 525-544.

Kardes, F. R. (2006). When should consumers and managers trust their intuition? Journal of Consumer Psychology, 16(1), 20-24.

Katz, D., \& Kahn, R. L. (1978). The social psychology of organizations. New York: Wiley.

Kelley, T., \& Littman, J. (2005). The ten faces of innovation. New York: Doubleday.

Khatri, N., \& Ng, H. A. (2000). The role of intuition in strategic decision making. Human Relations, 53(1), 57-86.

Klein, K. J., \& Kozlowski, S. W. J. (2000). Multilevel theory, research, and methods in organizations: Foundations, extensions, and new directions. San Francisco, C.A.: Jossey-Bass.

Kogut, B., \& Zander, U. (1992). Knowledge of the firm, combinative capabilities, and the replication of technology. Organization Science, 3(3), 383-397.

Kozlowski, S. W. J., \& Bell, B. S. (2003). Work groups and teams in organizations. In W. C. Borman, D. R. Ilgen, \& R. J. Klimoski (Eds.), Handbook of psychology: Industrial and organizational psychology (pp. 333-375). London: Wiley.

Kozlowski, S. W. J., \& Ilgen, D. R. (2006). Enhancing the effectiveness of work groups and teams. Psychological Science in the Public Interest, 7(3), 77-124.

Leavy, B. (2010). Design thinking-A new mental model of value innovation. Strategy and Leadership, 38(3), 5-14.

Leonard-Barton, D. (1995). Wellsprings of knowledge. Boston, M.A.: Harvard Business School Press.

LePine, J. A. (2003). Team adaptation and post change performance: Effects of team composition in terms of members' cognitive ability and personality. Journal of Applied Psychology, 88(1), 27.

Levinthal, D. A., \& March, J. G. (1993). The myopia of learning. Strategic Management Journal, 14(S2), 95-112.

Li, Y., Wang, J., Li, X., \& Zhao, W. (2007). Design creativity in product innovation. International Journal of Advanced Manufacturing Technology, 33(3/4), 213-222.

Martin, R. (2007). How successful leaders think. Harvard Business Review, 85(6), 60-67.

Martin, R. (2009). The design of business. Boston, M.A.: Harvard Business Press.

McCrae, R. R., \& Costa, P. T. (1987). Validation of the five-factor model of personality across instruments and observers. Journal of Personality and Social Psychology, 52(1), 81.

McDonagh, D., \& Thomas, J. (2010). Rethinking design thinking: Empathy supporting innovation. Australasian Medical Journal, 3(8), 458-464.

Merriam, S. B. (1998). Qualitative research and case study applications in education. San Francisco, C.A.: Jossey-Bass Publishers.

Mullen, B., \& Copper, C. (1994). The relation between group cohesiveness and performance: An integration. Psychological Bulletin, 115(2), 210.

O’Leary-Kelly, A. M., Martocchio, J. J., \& Frink, D. D. (1994). A review of the influence of group goals on group performance. Academy of Management Journal, 3(7), 1285-1301.

O’Neill, T. A., \& Allen, N. J. (2011). Personality and the prediction of team performance. European Journal of Personality, 25(1), 31-42.

Oldham, G. R., \& Cummings, A. (1996). Employee creativity: Personal and contextual factors at work. Academy of Management 
Journal, 39(3), 607-634.

Papenhausen, C. K. (2004). Half full or half empty: The effects of top managers' dispositional optimism on strategic decision-making and firm performance. Journal of Behavioral and Applied Management, 7(2), 103-115.

Parker, G. M. (1990). Team players and teamwork. San Francisco: Jossey- Bass

Patton, M. Q. (2002). Qualitative research and evaluation methods. Thousand Oaks, C.A.: Sage Publications, Inc..

Peeters, M. A. G., Van Tuijl, H. F. J. M., Rutte, C. G., \& Reymen, I. M. M. J. (2006). Personality and team performance: A meta analysis. European Journal of Personality, 20(5), 377-396.

Peterson, R. S., Owens, P. D., Tetlock, P. E., Fan, E. T., \& Martorana, P. (1998). Group dynamics in top management teams: Groupthink, vigilance, and alternative models of organizational failure and success. Organizational Behavior and Human Decision Processes, 73(1998), 272-305.

Rhee, J., Park, T., \& Lee, D. H. (2010). Drivers of innovativeness and performance for innovative SMEs in South Korea: Mediation of learning orientation. Technovation, 30(1), 65-75.

Rushmer, R. K. (1996). Is Belbin’s shaper really TMS’s thruster-organizer? An empirical investigation into the correspondence between the Belbin and TMS team role models. Leadership and Organization Development Journal, 17(1), 20-26.

Sadler-Smith, E., \& Shefy, E. (2004). The intuitive executive: Understanding and applying "gut feel" in decision-making. The Academy of Management Executive, 18(4), 76-91.

Sakkab, N. Y. (2007). Growing through innovation. Research Technology Management, 50(6), 59-64.

Schippers, M. C., West, M., \& Dawson, J. (2010). Team reflexivity and innovation: The moderating role of team context. Proceedings from the Academy of Management Annual Meeting (pp. 1-6). Montreal, Canada.

Seligman, M. E. P., \& Nathan, E. (1998). Learned optimism. New York: Knopf.

Senior, B. (1997). Team roles and team performance: Is there "really" a link? Journal of Occupational and Organizational Psychology, 70(3), 241.

Sole, D., \& Wilson, D. G. (1999). Storytelling in organizations: The power and traps of using stories to share knowledge in organizations. Training and Development, 53(3), 44-52.

Sørensen, F., Mattsson, J., \& Sundbo, J. (2010). Experimental methods in innovation research. Research Policy, 39(3), $313-322$.

Spencer, J., \& Pruss, A. (1992). Managing your team. London: Piatkus.

Spreitzer, G. M., Kizilos, M. A., \& Nason, S. W. (1997). A dimensional analysis of the relationship between psychological empowerment and effectiveness satisfaction, and strain. Journal of Management, 23(5), 679-704.

Stewart, G. L., \& Barrick, M. R. (2000). Team structure and performance: Assessing the mediating role of intra team process and the moderating role of task type. The Academy of Management Journal, 43(2), 135-148.

Tang, H. K. (1998). An integrative model of innovation in organizations. Technovation, 18(5), 297-309.

Tashakkori, A. (2006). Mixed methodology: Combining qualitative and quantitative approaches. Thousand Oaks, C.A.: Sage Publications, Inc..

Tesolin, A. (2007). Don't stifle intuition in your workplace. Training and Development, 61(6), 76-78.

Thomke, S. H. (2003). Experimentation matters. Cambridge, M.A.: Harvard Business School Press.

Tjosvold, D., Yu, Z. Y., \& Wu, P. (2009). Empowering individuals for team innovation in China: Conflict management and problem solving. Negotiation and Conflict Management Research, 2(2), 185-205.

Van Kleef, G. A., Homan, A. C., Beersma, B., Van Knippenberg, D., Van Knippenberg, B., \& Damen, F. (2009). Searing sentiment or cold calculation? The effects of leader emotional displays on team performance depend on follower epistemic motivation. Academy of Management Journal, 52(3), 562-580.

West, G. P. (2007). Collective cognition: When entrepreneurial teams, not individuals, make decisions. Entrepreneurship: Theory and Practice, 31(1), 77-102.

West, J., \& Iansiti, M. (2003). Experience, experimentation, and the accumulation of knowledge: The evolution of R\&D in the semiconductor industry. Research Policy, 32(5), 809-825.

Wong, A., Tjosvold, D., \& Liu, C. (2009). Innovation by teams in Shanghai, China: Cooperative goals for group confidence and persistence. British Journal of Management, 20(2), 238-251.

Wouters, M., \& Roijmans, D. (2010). Using prototypes to induce experimentation and knowledge integration in the development of enabling accounting information. Twente: University of Twente.

Wylant, B. (2008). Design thinking and the experience of innovation. Design Issues, 24(2), 3-14.

Yin, R. K. (2009). Case study research: Design and methods. Thousand Oaks: Sage Publications, Inc.. 